Research Article

\title{
Cytotoxicity and genotoxicity of coronaridine from Tabernaemontana catharinensis A.DC in a human laryngeal epithelial carcinoma cell line (Hep-2)
}

\author{
Walace Fraga Rizo ${ }^{1}$, Luis Eduardo Ferreira ${ }^{1}$, Vanessa Colnaghi ${ }^{1}$, Juliana Simões Martins ${ }^{1}$, \\ Leonardo Pereira Franchi ${ }^{2}$, Catarina Satie Takahashi ${ }^{2}$, Rene Oliveira Beleboni ${ }^{1}$, Mozart Marins ${ }^{1}$, \\ Paulo Sérgio Pereira ${ }^{1}$ and Ana Lúcia Fachin ${ }^{1}$ \\ ${ }^{1}$ Unidade de Biotecnologia Vegetal, Universidade de Ribeirão Preto, Ribeirão Preto, SP, Brazil. \\ ${ }^{2}$ Departamento de Genética, Faculdade de Medicina de Ribeirão Preto, Universidade de São Paulo, \\ Ribeirão Preto, SP, Brazil.
}

\begin{abstract}
Cancer has become a major public health problem worldwide and the number of deaths due to this disease is increasing almost exponentially. In the constant search for new treatments, natural products of plant origin have provided a variety of new compounds to be explored as antitumor agents. Tabernaemontana catharinensis is a medicinal plant that produces alkaloids with expressive antitumor activity, such as heyneanine, coronaridine and voacangine. The aim of present study was firstly to screen the cytotoxic activity of the indole alkaloids heyneanine, coronaridine and voacangine against HeLa (human cervix tumor), 3T3 (normal mouse embryo fibroblasts), Hep-2 (human laryngeal epithelial carcinoma) and B-16 (murine skin) cell lines by MTT (3-(4,5-dimethylthiazol2-yl)-2,5-diphenyltetrazolium bromide); and secondly to analyze the apoptotic activity, cell membrane damage and genotoxicity of the compound that showed the best cytotoxic activity against the tumor cell lines tested. Coronaridine was the one that exhibited greater cytotoxic activity in the laryngeal carcinoma cell line Hep-2 $\left(\mathrm{IC}_{50}=54.47 \mu \mathrm{g} / \mathrm{mL}\right)$ than the other alkaloids tested (voacangine $I C_{50}=159.33 \mu \mathrm{g} / \mathrm{mL}$, and heyneanine $I C_{50}=689.45 \mu \mathrm{g} / \mathrm{mL}$ ). Coronaridine induced apoptosis in cell lines 3T3 and Hep-2, even at high concentrations. The evaluation of genotoxicity by comet assay showed further that coronaridine caused minimal DNA damage in the Hep-2 tumor cell line, and the LDH test showed that it did not affect the plasma membrane. These results suggest that further investigation of coronaridine as an antitumor agent has merit.
\end{abstract}

Keywords: 3T3, apoptosis, comet assay, indole alkaloid, LDH.

Received: May 9, 2012; Accepted: October 31, 2012.

\section{Introduction}

Although the advances in oncology have led to more effective treatments and cure, cancer continues to be one of the leading causes of human death (Jemal et al., 2011). Laryngeal cancer accounts for about $2.7 \%$ of all cancers and for $2.1 \%$ of all deaths due to cancer. According to the Brazilian National Institute of Cancer, in the State of São Paulo the number of cases of laryngeal cancer per 100,000 inhabitants estimated for 2012 will be 6.9-10.68 for men and 3.91-7.54 for women. Laryngeal cancer is one of the frequent head and neck cancers, accounting for approximately $25 \%$ of all malignant head and neck tumors. A major difficulty in preventing cancer progression is the increased re-

Send correspondence to Ana Lúcia Fachin. Unidade de Biotecnologia Vegetal, Universidade de Ribeirão Preto, Av. Costábile Romano 2201, 14096-900 Ribeirão Preto, SP, Brazil. E-mail: afachin@unaerp.br. sistance, low specificity and high toxicity of drugs that are commercially available (Riedl et al., 2011). The toxicity of chemotherapeutic agents is a decisive treatment factor, particularly in immunocompromised patients (Geard, 1992). The development of new cytotoxic compounds is therefore important, and evaluation of the genotoxic activity of the compounds in non-tumor cells is also necessary, to assure that the treatment is safe and has no serious side effects. Fucic et al. (1998) reported that few chemotherapeutic agents induce secondary tumors in patients with cancer. Apoptosis, or programmed cell death, is an essential process for the maintenance of the development of a living organism, by eliminating superfluous or defective cells. In addition to playing an important role in the control of various vital processes, apoptosis forms the basis of various cancer treatment strategies, in which apoptosis is induced in tumor cells in response to treatment with cytotoxic agents (Grivicich et al., 2007; Sayers, 2011). Necrosis is a 
type of cell death in which cells suffer damage that results in an increase of cell volume, chromatin aggregation, cytoplasm disorganization, loss of plasma membrane integrity and consequent cell rupture. The cell content is released, causing damage to neighboring cells and an inflammatory reaction at the site of injury (Kelekar, 2005).

Natural products are a rich source of new drugs, and a large number of substances with cytotoxic activity have been isolated from plants (Araujo and Leon, 2001; Lachenmeier et al., 2006; Castaneda et al., 2011; Li et al., 2011). For instance, Vincristine (Oncovin $\left.{ }^{\circledR}\right)$, an alkaloid found in species of the family Apocynaceae, is used as an antitumor agent in oncology. Like other secondary metabolites found in nature that are the active ingredients of anticancer drugs, such as paclitaxel, apoptolodin and bryostatin, vincristine blocks mitotic progression, causing metaphase arrest (Tsukamoto et al., 2011).

Tabernaemontana catharinensis A.DC, a plant of the family Apocynaceae, popularly known as "leiteiro de vaca" (cow's dogbane), found in Argentina, Paraguay, Brazil and Bolivia, is used by the population as anticancer remedy. The genus Tabernaemontana is rich in monoterpene indole alkaloids such as coronaridine, voacangine, hydroxycoronaridine, isovoacangine, 11-hydroxycoronaridine, voacristine, 19-epi-voacristine, isovoacristine, ibogamine, 10-metoxyibogamine, 11-metoxyibogamine, and 19-epiheyneanine (Kam and Sim, 2002; Prakash Chaturvedula et al., 2003). These indole alkaloids have numerous biological activities, including central nervous system-stimulating activity, antihypertensive, anticholinesterase, antimicrobial and antimalarial properties, and especially antitumor activity (van Beek et al., 1984; Perera et al., 1985; Delorenzi et al., 2001; Prakash Chaturvedula et al., 2003; de Almeida et al., 2004; Kam et al., 2004; Andrade et al., 2005; Vieira et al., 2008; Medeiros et al., 2011).

The present study investigated the cytotoxic activity of the indole alkaloids heyneanine, coronaridine and voacangine in different cell lines, using the MTT (3-(4,5dimethylthiazol-2-yl)-2,5-diphenyltetrazolium bromide) colorimetric assay. In view of the better cytotoxic activity presented by coronaridine, we evaluated apoptosis induction, cell membrane damage and genotoxicity of this compound in human laryngeal carcinoma (Hep-2) cells and in normal mouse embryo fibroblasts (3T3).

\section{Materials and Methods}

\section{Chemical agents}

Fetal bovine serum was purchased from Cultilab (Campinas, São Paulo, Brazil). Penicillin, streptomycin, doxorubicin, Dulbecco's modified Eagle's and HAM-F10 culture media, DMSO, isopropanol, MTT, actinomycin D, acridine orange, ethidium bromide and trypsin were purchased from Sigma Chemicals (St. Louis, MO, USA).

\section{Plant material}

Root barks of $T$. catharinensis were collected in Assis, São Paulo, Brazil, and a voucher specimen was deposited at the herbarium (SPFR) of FFCLRP, University of São Paulo, Ribeirão Preto, Brazil (Registration No. 02940).

\section{Purification of alkaloids}

The indole alkaloids coronaridine (COR), voacangine (VOA) and heyneanine (HEY) (Figure 1) were purified from an ethanolic extract of $T$. catharinensis root bark, as described by Pereira et al. (2008).

\section{Cytotoxicity testing}

Cells were cultured at $37{ }^{\circ} \mathrm{C}$ in a humidified atmosphere containing $5 \% \mathrm{CO}_{2}$ supplemented with $10 \%$ fetal bovine serum, using Dulbecco's modified Eagle's medium (Sigma) for culture of the HeLa (human cervix tumor), 3T3 (normal mouse embryo fibroblasts) and Hep-2 (human laryngeal epithelial carcinoma) cell lines. HAM-F10 medium was used for culturing B-16 cells (murine skin). Penicillin $(100 \mathrm{U} / \mathrm{mL})$ and streptomycin $(100 \mu \mathrm{g} / \mathrm{mL})$ were added to the medium to prevent bacterial growth. A stock solution $(10 \mathrm{mg} / \mathrm{mL})$ of each alkaloid was prepared in $10 \%$ DMSO. Each alkaloid (COR, VOA and HEY) was directly diluted in the medium, to obtain concentrations ranging from 15.62 to $1000 \mu \mathrm{g} / \mathrm{mL}$. The final concentration of DMSO was less than $1 \%$ and had no negative effects on the cell lines. Doxorubicin and actinomycin D $(8 \mu \mathrm{g} / \mathrm{mL})$ were used as positive controls. Cells were trypsinized $(0.15 \%$ trypsin and $0.02 \%$ EDTA), counted in a hemocytometer $\left(10^{5}\right.$ cells/well), and incubated in a 96-well plate for $24 \mathrm{~h}$. After addition of the alkaloid or vehicle dissolved in fresh medium, the cells were cultured at $37{ }^{\circ} \mathrm{C}$ in a $5 \% \mathrm{CO}_{2}$ atmosphere for $48 \mathrm{~h}$, and cytotoxicity was analyzed by the MTT assay (Mosmann, 1983). For this purpose, $20 \mu \mathrm{L} \mathrm{MTT/well}$ ( $5 \mathrm{mg} / \mathrm{mL}$ in Hanks solution) were added to the 96-well plate, and the assay was incubated for $4 \mathrm{~h}$ under the same conditions. All cell treatments were carried out in triplicate. The formazan dye formed was extracted with $200 \mu \mathrm{L}$ isopropanol and quantified spectrophotometrically at $550 \mathrm{~nm}$ in a thermo plate reader (Biotek ELx 800, Singapura). The absorbance of untreated cells was used as a reference. The

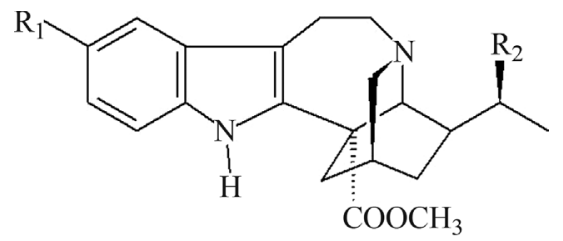

$1-\mathrm{R}_{1}=\mathrm{R}_{2}=\mathrm{H}$ Coronaridine

2 - $\mathrm{R}_{1}=\mathrm{OCH}_{3} ; \mathrm{R}_{2}=\mathrm{H}$ Voacangine

3 - $\mathrm{R}_{1}=\mathrm{H} ; \mathrm{R}_{2}=\mathrm{OH}$ Heyneanine

Figure 1 - Chemical structure of the indole alkaloids studied: coronaridine, heyneanine and voacangine. 
alkaloid found to be the most effective against the three tumor cell lines in the MTT assay was used in the next experiments (apoptosis, comet assay and lactate dehydrogenase activity measurement).

\section{Detection of apoptosis}

Apoptosis was analyzed as described by Ribble et al. (2005). Briefly, $2.0 \times 10^{5}$ cells were treated with COR for $48 \mathrm{~h}$, harvested by trypsinization, and centrifuged at $2500 \mathrm{rpm}(129 \mathrm{~g}$ ) for $5 \mathrm{~min}$. The cells were resuspended in $150 \mu \mathrm{L}$ acridine orange and ethidium bromide $(100 \mu \mathrm{g} / \mathrm{mL}$ each), and $20 \mu \mathrm{L}$ of the cell suspension was analyzed under a fluorescence microscope. The number of viable, apoptotic and necrotic cells was counted in 300 cells per treatment.

\section{Comet assay}

Hep-2 and 3T3 $\left(2 \times 10^{4}\right.$ cells $\left./ \mathrm{mL}\right)$ cells were incubated with $15.62,31.25,62.5$ and $125 \mu \mathrm{g} / \mathrm{mL}$ COR for $6 \mathrm{~h}$ at $37^{\circ} \mathrm{C}$ in a $5 \% \mathrm{CO}_{2}$ atmosphere. The alkaline comet assay was performed as described by McKelvey-Martin et al. (1993). Tice et al. (2000), and Liao et al. (2009), with minor modifications (Hartmann and Speit, 1997). Randomly selected cells ( 300 cells from each of three replicate slides, total $=900$ cells) were analyzed per COR concentration. Cells were visually scored regarding damage, divided into five classes, and the DNA damage index was calculated as described by Collins et al. (1995) and da Silva et al. (2000). Doxorubicin $(0.2 \mu \mathrm{g} / \mathrm{mL})$ was used as positive control and $1 \%$ DMSO as solvent control.

\section{Measurement of lactate dehydrogenase}

3T3 and Hep2 cells were incubated in 96-well plates $\left(2.5 \times 10^{5}\right.$ cells/well $)$ containing the adequate culture medium for each cell line in the presence of $15.62,31.25,62.5$, and $125 \mu \mathrm{g} / \mathrm{mL}$ of COR, respectively, at $37^{\circ} \mathrm{C}$ in a $5 \% \mathrm{CO}_{2}$ atmosphere, in triplicate. Then, $20 \mu \mathrm{L}$ cell-free culture supernatant were collected from each well and incubated with the appropriate reagent mixture, according to manufacturer instructions (Extracellular Lactate Dehydrogenase LDHe test from Xenometrix, Allschwil, Switzerland) at room temperature for $60 \mathrm{~min}$. The plates were read at $340 \mathrm{~nm}$ in a microplate reader (Biotek ELx 800, Singapore) at $0,10,20,30,40,50,60,70$, and $80 \mathrm{~min}$, respectively. The percentage of LDH released from treated cells into the culture was calculated by comparison with the maximal amount released by cells lysed with $1 \%$ Triton X-100 (positive control), according to the method described by Kornberg (1955).

\section{Data analysis}

The cytotoxicity results were analyzed by ANOVA (two paired samples for average) adopting a significance level of $\mathrm{p}<0.05$. $\mathrm{IC}_{50}$ values were calculated by nonlinear regression analysis. The comet assay, apoptosis and LDH test results are shown as mean \pm standard deviation, and were analyzed by one-way ANOVA, followed by Tukey's test.

\section{Results}

\section{Cytotoxic activity of indole alkaloids}

The MTT colorimetric assay was used to evaluate the cytotoxicity of the three alkaloids isolated from $T$. catharinensis in different tumor cell lines (Table 1). The highest cytotoxic activity $\left(\mathrm{IC}_{50}=54.47 \mu \mathrm{g} / \mathrm{mL}\right)$ was presented by coronaridine in the Hep-2 laryngeal carcinoma cell line as compared to the other alkaloids tested (voacangine: $159.33 \mu \mathrm{g} / \mathrm{mL}$, and heyneanine: $694.45 \mu \mathrm{g} / \mathrm{mL}$ ). The $\mathrm{IC}_{50}$ values of the positive controls were 1.57 and $0.81 \mu \mathrm{g} / \mathrm{mL}$ for doxorubicin and actinomycin $\mathrm{D}$, respectively. The pure alkaloids (coronaridine, voacangine and heyneanine) also exhibited cytotoxic activity against normal $3 \mathrm{~T} 3$ cells, with $\mathrm{IC}_{50}$ values of $89.28,104.16$ and $289.15 \mu \mathrm{g} / \mathrm{mL}$, respectively, indicating that these alkaloids are not specific for tumor cells.

\section{Detection of apoptosis}

Coronaridine induced apoptosis in 3T3 (Figure 2A) and Hep-2 (Figure 2B) cells at all concentrations tested, even at the highest concentration of $125 \mu \mathrm{g} / \mathrm{mL}$. In contrast, doxorubicin more frequently induced cell necrosis rather than apoptosis.

\section{Comet assay}

The results of the comet assay showed that incubation of cells with coronaridine for $6 \mathrm{~h}$ induced DNA damage

Table 1 - $\mathrm{IC}_{50}$ values $(\mu \mathrm{g} / \mathrm{mL})$ for the alkaloids coronaridine, heyneanine and voacangine.

\begin{tabular}{|c|c|c|c|c|c|}
\hline Cell line & $\mathrm{COR}$ & VOA & HEY & Doxorubicin & Actinomycin D \\
\hline $\mathrm{HeLa}$ & 146.32 & 271.97 & 637.76 & 2.41 & 1.70 \\
\hline B-16 & $<125$ & 439.16 & 749.39 & 2.61 & $\mathrm{ND}^{1}$ \\
\hline Hep-2 & 54.47 & 159.33 & 694.45 & 1.57 & 0.81 \\
\hline $3 \mathrm{~T} 3$ & 89.28 & 104.16 & 289.15 & $\mathrm{ND}^{1}$ & 2.90 \\
\hline
\end{tabular}

COR: coronaridine; VOA: voacangine; HEY: heyneanine; ND: not determined.

${ }^{1} \mathrm{The}_{\mathrm{IC}} \mathrm{C}_{50}$ value was not determined because the substance exhibited $<50 \%$ growth inhibition at the highest concentration tested $(1000 \mu \mathrm{g} / \mathrm{mL})$. 

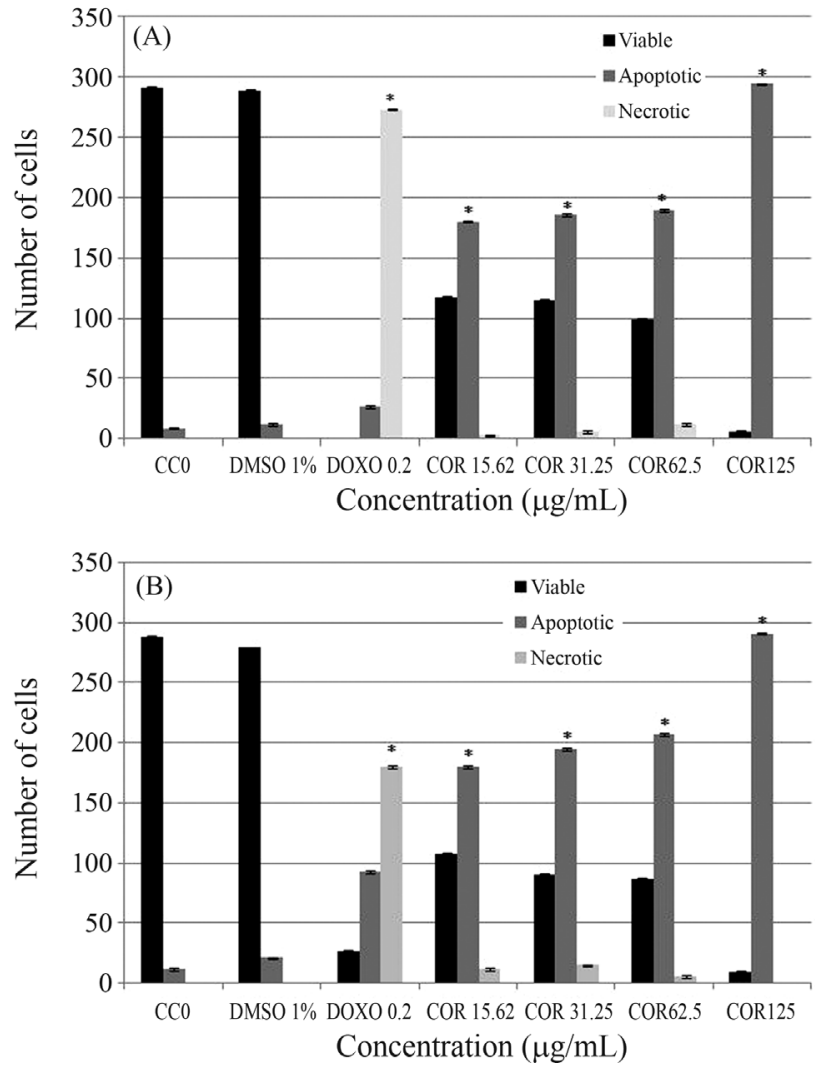

Figure 2 - Number of viable, apoptotic and necrotic cells of the 3T3 (A) and Hep-2 (B) cell lines, cultured for $48 \mathrm{~h}$ in the presence of different concentrations of coronaridine. $\mathrm{p}<0.05$ compared with control, by ANOVA followed by Tukey's test.

only in the Hep-2 tumor cell line, at all concentrations tested (including the highest concentration) when compared to the negative control. Doxorubicin produced a higher DNA damage index in normal $3 \mathrm{~T} 3$ cells than the highest concentration of coronaridine $(125 \mu \mathrm{g} / \mathrm{mL})$. At the concentrations of 62.5 and $125 \mu \mathrm{g} / \mathrm{mL}$, coronaridine induced greater DNA damage in the Hep-2 cell line than in the normal 3T3 cells. Compared to the commercially available chemotherapeutic agent doxorubicin, which presented a DNA damage index of 500 at the concentration of $0.2 \mu \mathrm{g} / \mathrm{mL}$, the genotoxocity of coronaridine was low (Figure 3 ).

\section{Lactate dehydrogenase activity}

The LDH measurements showed that, at the concentrations tested, coronaridine did not increase LDH activity in either the Hep-2 tumor cells or the normal 3T3 cells (data not shown). These results suggest that this alkaloid does not cause damage to the cell membrane the cell lines tested.

\section{Discussion}

Of the indole alkaloids tested (coronaridine, voacangine and heyneanine), coronaridine showed the best

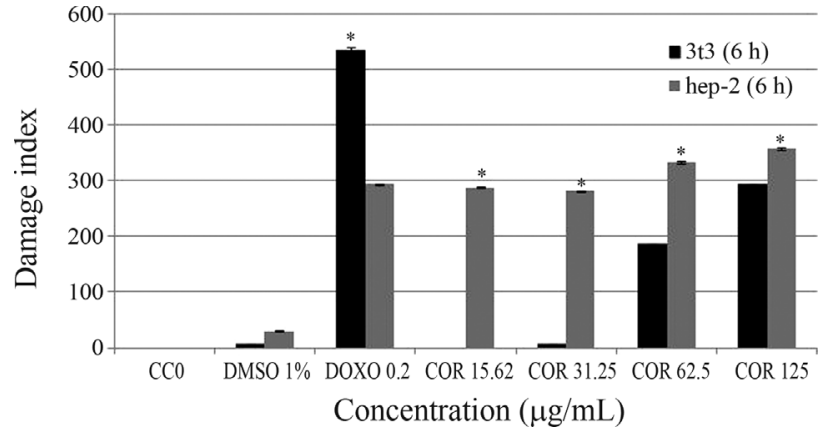

Figure 3 - DNA damage index of cells lines Hep-2 and $3 \mathrm{~T} 3$ treated with different concentrations of coronaridine for $6 \mathrm{~h}$, analyzed by the comet assay. ${ }^{*} \mathrm{p}<0.05$ compared with control, by ANOVA followed by Tukey's test.

cytotoxic activity against the human laryngeal carcinoma cell line Hep-2. We evaluated the cytotoxic activity of pure coronaridine, voacangine and heyneanine because of their structural similarity, since they all contain an indole group that characterizes their function. Coronaridine is characterized by the presence of a functional ether group in the aromatic ring, whereas voacangine and heyneanine present no substitution in the aromatic ring. The presence of this ether group in the aromatic ring may explain the greater cytotoxic activity of coronaridine against Hep-2 cells (Figueiredo et al., 2010). Coronaridine was also cytotoxic to the normal 3T3 cell line, demonstrating that this activity is not specific for tumor cells. This feature is often reported for current chemotherapeutic agents. The most commonly used anticancer drugs simply kill tumor cells, but also damage or kill neighboring healthy cells (Mancebo et al., 2002).

Indole alkaloids purified from other Tabernaemontana species presented cytotoxic activity against both vincristine-sensitive $(\mathrm{KB} / \mathrm{S})$ and -resistant (KB/VJ300) epidermoid carcinoma cell lines (van Beek et al., 1984; Kam et al., 2004). These authors obtained $\mathrm{IC}_{50}$ values of 11.5 and $2.6 \mu \mathrm{g} / \mathrm{mL}$ for coronaridine, $>25$ and $8.56 \mu \mathrm{g} / \mathrm{mL}$ for heyneanine, $>25$ and $>25 \mu \mathrm{g} / \mathrm{mL}$ for voacangine, and $>25$ and $>25 \mu \mathrm{g} / \mathrm{mL}$ for ibogamine in the $\mathrm{KB} / \mathrm{S}$ and $\mathrm{KB} / \mathrm{VJ} 300$ lines, respectively. These results demonstrate that coronaridine and heyneanine reversed the process of multiple drug resistance in the vincristine-resistant cell line. Bradacs et al. (2010) evaluated the cytotoxic activity of a methanol extract of Tabernaemontana pandacaqui. This extract exhibited potent activity against renal cancer cells (786-0), with an $\mathrm{IC}_{50}$ value of $4.62 \mu \mathrm{g} / \mathrm{mL}$. The ethyl acetate extract of this species reduced the viability of lung cancer cells $\left(\mathrm{IC}_{50}\right.$ of $13.46 \mu \mathrm{g} / \mathrm{mL}$ ). The present study showed that purified coronaridine from $T$. catharinensis has a moderate cytotoxic activity against the larynx carcinoma cell line tested, with an $\mathrm{IC}_{50}$ value higher than that obtained for $T$. pandacaqui tested in renal cancer cells. This finding might be due to differences between the types of cell lines used in the cytotoxicity assay. Although coronaridine exhibited a 
moderate cytotoxic activity, analysis of its mechanism of action showed that it induced apoptosis, did not cause damage to the cell membrane (as demonstrated by the LDH test), and caused minimal DNA damage (as determined by the comet assay). The commercial chemotherapeutic agent doxorubicin induced necrosis in the Hep-2 tumor cell line and even more so in normal 3T3 fibroblasts. Furthermore, doxorubicin caused greater DNA damage in normal than in tumor cells when compared to coronaridine. Carvalho et al. (2010) compared the effect of the anthracycline cosmomycin D and doxorubicin in DNA repair-deficient cell lines (XP-A and XP-C). Treatment of XP-A and XP-C cells with cosmomycin $\mathrm{D}$ induced apoptosis in a time-dependent manner. The highest degree of apoptosis was observed after $96 \mathrm{~h}$ of treatment and the effects of this drug were similar to those of doxorubicin. Cosmomycin D was also found to cause DNA damage in the comet assay, however a markedly lower one than that caused by doxorubicin.

Figueiredo et al. (2010) tested the alkaloids coronaridine, (19S)-heyneanine, isovoacangine, isovoacristine and voacangine isolated from Tabernaemontana salzmannii and observed satisfactory cytotoxic activity against human leukemia cells (THP-1). Cell death due to apoptosis was detected in $100 \%$ of cells. Voacangine induced apoptosis in $80 \%$ of cells treated with $100 \mu \mathrm{mol}$ of the compound within a period of $24 \mathrm{~h}$, whereas isovoacangine induced apoptosis in $80 \%$ of cells within a period of $6 \mathrm{~h}$ when tested at a concentration of $100 \mu \mathrm{mol}$. No acridine-orange-stained cells were observed at any of the time points studied, suggesting that the alkaloids tested did not induce cell death by necrosis. Induction of apoptosis is the mechanism of action of various antineoplastic drugs, such as Taxol and cisplatin. The ability to induce apoptosis is therefore used as a screening tool for substances with antitumor activity (Kam and Sim, 2002). In this respect, monoterpene indole alkaloids isolated from the methanol extract of Tabernaemontana elegans leaves has been shown to induce apoptosis in human hepatoma cells (HuH-7) (Mansoor et al., 2009).

In conclusion, of the indole alkaloids tested (heyneanine, coronaridine and voacangine), coronaridine exhibited the greatest cytotoxic activity in the larynx carcinoma cell line used. When screening natural products for cytotoxicity, their genotoxic activity must be be taken into consideration, to prevent secondary tumors after treatment. Although coronaridine has a moderate cytotoxic activity, it presents advantages due to its mechanism of action. This alkaloid induced apoptosis in Hep cells even at high concentrations, caused minimal DNA damage only in the tumor cell line, and did not affect the cell plasma membrane.

\section{Acknowledgments}

The authors thank Fundação de Amparo à Pesquisa do Estado de São Paulo (FAPESP) for financial support (grant 2010/06245-7) and Pele Nova-Biotecnologia for the fellowship granted to W.F.R. We thank the staff of the Biotechnology Unit at UNAERP, for general support.

\section{References}

Andrade MT, Lima JA, Pinto AC, Rezende CM, Carvalho MP and Epifanio RA (2005) Indole alkaloids from Tabernaemontana australis (Muell. Arg) Miers that inhibit acetylcholinesterase enzyme. Bioorg Med Chem 13:4092-4095.

Araujo CC and Leon LL (2001) Biological activities of Curcuma longa L. Mem Inst Oswaldo Cruz 96:723-728.

Bradacs G, Maes L and Heilmann J (2010) In vitro cytotoxic, antiprotozoal and antimicrobial activities of medicinal plants from Vanuatu. Phytother Res 24:800-809.

Carvalho H, Garrido LM, Furlan RL, Padilla G, Agnoletto M, Guecheva T, Henriques JA, Saffi J and Menck CF (2010) DNA damage induced by the anthracycline cosmomycin D in DNA repair-deficient cells. Cancer Chemother Pharmacol 65:989-994.

Castaneda SA, Tellez MG, Ocotero VM, Carballo-Ontiveros MA, García AM, Valdés RJ, Gutiérrez ER and Rodríguez-Arnaiz R (2011) Chronic toxicity, genotoxic assay, and phytochemical analysis of four traditional medicinal plants. J Med Food 14:1018-1022.

Collins AR, Ma AG and Duthie SJ (1995) The kinetics of repair of oxidative DNA damage (strand breaks and oxidised pyrimidines) in human cells. Mutat Res 336:69-77.

da Silva J, de Freitas TR, Heuser V, Marinho JR and Erdtmann B (2000) Genotoxicity biomonitoring in coal regions using wild rodent Ctenomys torquatus by Comet assay and micronucleus test. Environ Mol Mutagen 35:270-278.

de Almeida L, Cintra AC, Veronese EL, Nomizo A, Franco JJ, Arantes EC, Giglio JR and Sampaio SV (2004) Anticrotalic and antitumoral activities of gel filtration fractions of aqueous extract from Tabernaemontana catharinensis (Apocynaceae). Comp Biochem Physiol C Toxicol Pharmacol 137:19-27.

Delorenzi JC, Attias M, Gattass CR, Andrade M, Rezende C, da Cunha Pinto A, Henriques AT, Bou-Habib DC and Saraiva EM (2001) Antileishmanial activity of an indole alkaloid from Peschiera australis. Antimicrob Agents Chemother 45:1349-1354.

Figueiredo ER, Vieira IJC, Souza JJD, Braz-Filho R, Mathias L, Kanashiro MM and Côrtes FH (2010) Isolamento, identificação e avaliação da atividade antileucêmica de alcaloides indólicos monoterpênicos de Tabernaemontana salzmannii (A. DC.), Apocynaceae. Rev Bras Farmacogn 20:675-681 (Abstract in English).

Fucic A, Jazbec A, Mijic A, Seso-Simic D and Tomek R (1998) Cytogenetic consequences after occupational exposure to antineoplastic drugs. Mutat Res 416:59-66.

Geard CR (1992) Cytogenetic assays for genotoxic agents. Lens Eye Toxic Res 9:413-428.

Grivicich I, Regner A and Rocha AB (2007) Morte celular por apoptose. Rev Bras Cancerol 53:335-343.

Hartmann A and Speit G (1997) The contribution of cytotoxicity to DNA-effects in the single cell gel test (comet assay). Toxicol Lett 90:183-188. 
Jemal A, Bray F, Center MM, Ferlay J, Ward E and Forman D (2011) Global cancer statistics. Cancer J Clin 61:69-90.

Kam TS and Sim KM (2002) Five new iboga alkaloids from Tabernaemontana corymbosa. J Nat Prod 65:669-672.

Kam TS, Sim KM, Pang HS, Koyano T, Hayashi M and Komiyama K (2004) Cytotoxic effects and reversal of multidrug resistance by ibogan and related indole alkaloids. Bioorg Med Chem Lett 14:4487-4489.

Kelekar A (2005) Autophagy. Ann N Y Acad Sci 1066:259-271.

Lachenmeier DW, Walch SG, Padosch SA and Kroner LU (2006) Absinthe - A review. Crit Rev Food Sci Nutr 46:365-377.

Li N, Xia Q, Ruan J, Fu PP and Lin G (2011) Hepatotoxicity and tumorigenicity induced by metabolic activation of pyrrolizidine alkaloids in herbs. Curr Drug Metab 12:823-834.

Liao W, McNutt MA and Zhu WG (2009) The comet assay: A sensitive method for detecting DNA damage in individual cells. Methods 48:46-53.

Mancebo F, Hilje L, Mora GA and Salazar R (2002) Biological activity of two neem (Azadirachta indica A. Juss., Meliaceae) products on Hypsipyla grandella (Lepidoptera, Pyralidae) larvae. Crop Protect 21:107-112.

Mansoor TA, Ramalho RM, Mulhovo S, Rodrigues CM and Ferreira MJ (2009) Induction of apoptosis in HuH-7 cancer cells by monoterpene and beta-carboline indole alkaloids isolated from the leaves of Tabernaemontana elegans. Bioorg Med Chem Lett 19:4255-4258.

McKelvey-Martin VJ, Green MH, Schmezer P, Pool-Zobel BL, De Méo MP and Collins A (1993) The single cell gel electrophoresis assay (comet assay): A European review. Mutat Res 288:47-63.

Medeiros MR, Prado LA, Fernandes VC, Figueiredo SS, Coppede J, Martins J, Fiori GM, Martinez-Rossi NM, Beleboni RO, Contini SH, et al. (2011) Antimicrobial activities of indole alkaloids from Tabernaemontana catharinensis. Nat Prod Commun 6:193-196.

Mosmann T (1983) Rapid colorimetric assay for cellular growth and survival: Application to proliferation and cytotoxicity assays. J Immunol Methods 65:55-63.

Pereira PS, França SC, Oliveira PVAO, Breves CMS, Pereira SIV, Sampaio SV, Nomizo A and Dias DA (2008) Chemical constituents from Tabernaemontana catharinensis root bark: A brief NMR review of indole alkaloids and in vitro cytotoxicity. Quim Nova 31:20-24.

Perera P, Kanjanapothy D, Sandberg F and Verpoorte R (1985) Muscle relaxant activity and hypotensive activity of some Tabernaemontana alkaloids. J Ethnopharmacol 13:165-173.

Prakash Chaturvedula VS, Sprague S, Schilling JK and Kingston DG (2003) New cytotoxic indole alkaloids from Tabernaemontana calcarea from the Madagascar rainforest. J Nat Prod 66:528-531.

Ribble D, Goldstein NB, Norris DA and Shellman YG (2005) A simple technique for quantifying apoptosis in 96-well plates. BMC Biotechnology 5:e12.

Riedl S, Zweytick D and Lohner K (2011) Membrane-active host defense peptides - Challenges and perspectives for the development of novel anticancer drugs. Chem Phys Lipids 164:766-781.

Sayers TJ (2011) Targeting the extrinsic apoptosis signaling pathway for cancer therapy. Cancer Immunol Immunother 60:1173-1180.

Tice RR, Agurell E, Anderson D, Burlinson B, Hartmann A, Kobayashi H, Miyamae Y, Rojas E, Ryu JC and Sasaki YF (2000) Single cell gel/comet assay: Guidelines for in vitro and in vivo genetic toxicology testing. Environ Mol Mutagen 35:206-221.

Tsukamoto A, Ohno K, Tsukagoshi T, Maeda S, Nakashima K, Fukushima K, Fujino Y, Takeuchi A and Tsujimoto $\mathrm{H}$ (2011) Ultrasonographic evaluation of vincristine-induced gastric hypomotility and the prokinetic effect of mosapride in dogs. J Vet Intern Med 25:1461-1464.

van Beek TA, Deelder AM, Verpoorte R and Svendsen AB (1984) Antimicrobial, antiamoebic and antiviral screening of some Tabernaemontana species. Planta Med 50:180-185.

Vieira IJ, Medeiros WL, Monnerat CS, Souza JJ, Mathias L, Braz-Filho R, Pinto AC, Sousa PM, Rezende CM and Epifanio RA (2008) Two fast screening methods (GC-MS and TLC-ChEI assay) for rapid evaluation of potential anticholinesterasic indole alkaloids in complex mixtures. An Acad Bras Cienc 80:419-426.

Associate Editor: Daisy Maria Fávero Salvadori

License information: This is an open-access article distributed under the terms of the Creative Commons Attribution License, which permits unrestricted use, distribution, and reproduction in any medium, provided the original work is properly cited. 